\title{
PRAVO NA UVID U SPIS U UPRAVNIM STVARIMA
}

\author{
Izv. prof. dr. sc. Lana Ofak* \\ Izv. prof. dr. sc. Marko Šikić**
}

\author{
UDK: 35.077 .2 \\ https://doi.org/10.30925/zpfsr.40.1.16 \\ Ur.: 2. siječnja 2019. \\ Pr.: 10. veljače 2019. \\ Pregledni znanstveni rad
}

\begin{abstract}
Sažetak
$U$ radu se analiziraju bitna pitanja vezana za ostvarivanje prava na uvid $u$ spis u upravnim stvarima. Tako se u radu, nakon uvodnog poglavlja, najprije ukazuje na ustavni rang prava na uvid u spis kao sastavnog dijela prava na pravični postupak. S obzirom na činjenicu da je riječ o pravu koje je zaštićeno $i$ Konvencijom za zaštitu ljudskih prava i temeljnih sloboda, koju su javnopravna tijela u Republici Hrvatskoj dužna primjenjivati, u radu je prikazana i praksa Europskog suda za ljudska prava. U središnjem dijelu rada analiziraju se pitanja ovlaštenika prava na uvid u spis, izuzimanja pojedinih spisa od razgledavanja i umnažanja, načina sastavljanja izreke i obrazloženja rješenja kojim se uvid u spis odbija, primjene načela razmjernosti pri odlučivanju o ograničavanju prava na uvid te vremena ostvarivanja prava na uvid u spis. U zaključku rada naglašava se kako se osiguravanjem uvida u spis u upravnim stvarima u konačnici postiže i veća kvaliteta rješenja javnopravnih tijela te osigurava zakonitost u funkcioniranju javne uprave.
\end{abstract}

Ključne riječi: uvid u spis; pravični postupak; Zakon o općem upravnom postupku; Ustav Republike Hrvatske; Konvencija za zaštitu ljudskih prava i temeljnih sloboda.

\section{UVOD}

Jedno od temeljnih prava nužnih za zaštitu prava i pravnih interesa stranaka u svim upravnim postupcima jest pravo stranke biti obaviještena o svim činjeničnim i pravnim pitanjima koja se pojavljuju u postupku u kojem se odlučuje o njezinim pravima, obvezama i pravnim interesima. ${ }^{1}$ Način kako se u postupku osigurava ostvarenje tog prava jest putem prava stranke na obavješćivanje o tijeku postupka te na uvid u spis predmeta o kojem rješava javnopravno tijelo (članak 84. Zakona

* Dr. sc. Lana Ofak, izvanredna profesorica, Pravni fakultet Sveučilišta u Zagrebu; lana.ofak@, pravo.hr.

** Dr. sc. Marko Šikić, izvanredni profesor, Pravni fakultet Sveučilišta u Zagrebu; marko.sikic@ pravo.hr.

1 Đerđa, D., Pravila upravnog postupka u europskom pravu, Zbornik Pravnog fakulteta Sveučilišta u Rijeci, v. 33, 1/2012, str. 130-131. 
o općem upravnom postupku² (dalje: ZUP)). Iako je riječ o jednom od temeljnih procesnih prava stranaka zajamčenog člankom 29. stavkom 1. Ustava Republike Hrvatske (dalje: Ustav, v. poglavlje 2.), ${ }^{3}$ kao i člankom 6. stavkom 1. Konvencije za zaštitu ljudskih prava i temeljnih sloboda (dalje: Europska konvencija ili Konvencija, v. poglavlje 3.), ${ }^{4}$ o toj problematici u hrvatskoj upravno-pravnoj literaturi ne postoje samostalni znanstveni radovi, već se o njoj raspravlja u okviru širih tema. ${ }^{5}$

Načelo pristupa podatcima izrijekom je propisano kao jedno od temeljnih načela upravnog postupka (članak 11. ZUP-a). Međutim, osim pristupa podatcima, u upravnom postupku mora se osigurati i zaštita podataka, sukladno propisima o zaštiti osobnih podataka, odnosno tajnosti podataka (članak 11. stavak 2. ZUP-a). To je iz razloga što je u upravnim postupcima moguće postojanje suprotstavljenih interesa, kao što je, primjerice, potreba za čuvanjem tajnosti podataka ili potreba za zaštitom prava trećih osoba, koji se moraju odvagati u odnosu na prava pojedinca, tj. stranke.

U ovom će se radu analizirati bitna pitanja vezana za ostvarivanje prava na uvid u spis u upravnim stvarima koja uključuju ovlaštenike tog prava, izuzimanja pojedinih spisa od razgledavanja i umnažanja, način sastavljanja izreke i obrazloženja rješenja kojim se uvid odbija, primjenu načela razmjernosti pri odlučivanju o ograničavanju prava na uvid te vrijeme ostvarivanja prava (poglavlje 4.). Prije svega rad je nužno započeti s objašnjenjem ustavnoga ranga prava na uvid u spis kao sastavnog dijela prava na pravični postupak (poglavlje 2.) kako bi se u cijelosti mogla razumjeti problematika koja analizira u radu. Osim toga, budući da je riječ o pravu koje je zaštićeno i Europskom konvencijom koju su javnopravna tijela u Hrvatskoj dužna primjenjivati, potrebno je i prikazati praksu Europskog suda za ljudska prava (poglavlje 3.).

\section{PRAVO NA UVID U SPIS KAO PROCESNO PRAVO STRANAKA ZAJAMČENO USTAVOM}

Pravo na uvid u spis u upravnim stvarima jedno je od temeljnih procesnih prava stranaka koje proizlazi iz Ustava kojim se jamči pravo na pravični postupak. Ustavno pravo na pravično suđenje, zaštićeno člankom 29. stavkom 1. Ustava, ${ }^{6}$ jamči pravnu zaštitu stranaka u odlučivanju sudova, ali i drugih državnih odnosno javnopravnih tijela. Naime, Ustavni sud Republike Hrvatske (dalje: Ustavni sud) opetovano u svojim odlukama ponavlja da pravo na pravično suđenje jamči svakome pravičnost postupka pred svim tijelima koja odlučuju o njegovim pravima i obvezama. Dakle, ne samo pred sudovima nego i pred svim drugim tijelima ovlaštenim za odlučivanje o

2 NN, br. $47 / 09$.

3 NN, br. 56/90., 135/97., 113/00., 28/01., 76/10. i 5/14.

4 NN - MU, br. 18/97., 6/99. - pročišćeni tekst, 8/99. - ispravak, 14/02. i 1/06.

5 V. primjerice, Đerđa, D., Pravila, str. 130-131; id., Učinak europskih pravnih pravila na pravno normiranje upravnog postupka u Hrvatskoj, Zbornik radova Pravnog fakulteta u Splitu, vol. 50, 2/2013, str. 412-414.

6 Članak 29. stavak 1. Ustava u svom relevantnom dijelu glasi: „,Svatko ima pravo da zakonom ustanovljeni neovisni i nepristrani sud pravično i u razumnom roku odluči o njegovim pravima i obvezama ...". 
pravima i obvezama građana i drugih osoba. ${ }^{7}$

Primijenjeno na upravni postupak, ovo ustavno pravo zahtijeva da javnopravna tijela vode upravni postupak uz poštovanje osnovnog pravila o pravu stranke na izjašnjavanje o svim činjenicama, okolnostima i pravnim pitanjima važnim za rješavanje upravne stvari (članak 30. stavak 1. ZUP-a). To joj pravo omogućava da se pravovremeno zaštiti u postupku protiv svih djelovanja koja mogu utjecati na njezina prava, obveze ili pravne interese. Pravo na obaviještenost stranke o stanju postupka te pravo uvida u spis predmeta nužan su preduvjet za izjašnjavanje stranke u upravnom postupku, jer ona, prije negoli se izjasni, mora znati o kojim se činjeničnim i pravnim pitanjima uopće treba izjasniti i u kojem smjeru. ${ }^{8}$

Povezanost prava uvida u spis s člankom 29. stavkom 1. Ustava Ustavni sud podrobno je obrazložio u predmetu U-I-448/2009 $\mathrm{i} \mathrm{dr.}{ }^{9} \mathrm{u}$ kojem je ocijenio neustavnima pojedine odredbe Zakona o kaznenom postupku (NN, br. 152/08., 76/09. i 80/11.). Iako je riječ o dvama različitim postupcima, obrazloženje Ustavnog suda koje se odnosi na važnost prava uvida u spis predmeta u kaznenom postupku smatramo primjenjivim i na upravni postupak, budući da je u oba slučaja riječ o pravno uređenim postupcima koji potpadaju pod doseg prava na pravično suđenje. U tom smislu, prilagođeno na termine svojstvene za upravni postupak, smatramo da se iz odluke Ustavnog suda U-I448/2009 i dr. (točka 97.2.) ${ }^{10}$ mogu izvesti sljedeća stajališta koja bi se primjenjivala na uvid $\mathrm{u}$ spis u upravnim stvarima:

- Pravo uvida u spis predmeta (prema terminologiji ZUP-a: pravo razgledavanja spisa), kao inherentni dio prava na izjašnjavanje stranke i njezinog prava na sudjelovanje u postupku, ${ }^{11}$ izvodi se iz članka 29. stavka 1. Ustava.

- Pravo uvida u spis predmeta i pravo na predlaganje i izvođenje dokaza osnove su prava na izjašnjavanje stranke u upravnom postupku.

- Uvid u spis predmeta omogućava spoznaju stranke o svim činjenicama i okolnostima koje su bitne za rješavanje upravne stvari, kao i pravo na

7 V. primjerice odluku Ustavnog suda br. U-III-281/2018 od 22. svibnja 2018., točke 18. i 24.

8 Đerđa, D., Učinak..., op. cit., str. 412.

9 Odluka Ustavnog suda br. U-I-448/2009 i dr. od 19. srpnja 2012.

10 „Ustavni sud podsjeća da se pravo uvida u spis predmeta (prema terminologiji ZKP-a: pravo razgledavanja spisa), kao inherentni dio prava na obranu, izvodi iz članka 29. stavka 2. alineje 1. Ustava [...] Pravo uvida u spis predmeta i pravo na predlaganje i izvođenje dokaza osnove su prava obrane u kaznenom postupku. Uvid u spis predmeta omogućava spoznaju o tome što se okrivljeniku stavlja na teret, koji su dokazi za to pribavljeni i druge informacije. Bez prava uvida u spis predmeta pravo na obranu je nudum ius. Djelotvornim ostvarenjem tog prava osumnjičenik odnosno okrivljenik dobiva aktivnu ulogu i prelazi iz "objekta istrage" $u$ subjekt kaznenog postupka. O tom pravu u velikoj mjeri ovisi poštenost kaznenog postupka $i$ funkcioniranja pravne države u okvirima kaznenog pravosuđa."

11 Umjesto „prava na obranu“ smatramo primjerenijim u kontekstu upravnog postupka koristiti termin „,pravo na izjašnjavanje stranke“. Izjašnjavanje stranke propisano je u članku 30. ZUP-a koji glasi:

„(1) U postupku stranci se mora omogućiti izjašnjavanje o svim činjenicama, okolnostima $i$ pravnim pitanjima važnim za rješavanje upravne stvari.

(2) Bez prethodnog izjašnjavanja stranke postupak se može provesti samo ako se usvaja zahtjev stranke ili ako odluka u postupku nema negativan učinak na pravne interese stranke ili kad je tako propisano zakonom." 
pobijanje točnosti navoda koji se ne slažu s njezinim navodima (članak 52. stavak 1. ZUP-a).

- Bez prava uvida u spis predmeta pravo stranke na izjašnjavanje u postupku je nudum ius (,golo“ pravo bez sadržaja).

- Djelotvornim ostvarenjem prava uvida u spis predmeta stranka dobiva aktivnu ulogu i prelazi iz ,objekta“ u subjekt upravnog postupka.

- O pravu uvida u spis predmeta u velikoj mjeri ovisi pravičnost upravnog postupka i funkcioniranje pravne države u okvirima javnopravnih tijela.

Pravo na pravični postupak zajamčeno člankom 29. stavkom 1. Ustava nije apsolutno pravo već je podložno dopuštenim ograničenjima. Prema ustaljenoj praksi Ustavnog suda, granicu dopustivosti pojedinog ograničenja označava zahtjev da je ono propisano na takav način i u takvoj mjeri da ne narušava bit prava, da teži legitimnom cilju i da postoji razumni odnos razmjernosti između upotrijebljenog sredstva ograničavanja i cilja koji se njime nastoji ostvariti. ${ }^{12}$ To znači da pravo na uvid u spis može biti ograničeno zbog nekoga drugog legitimnog suprotstavljenog interesa, primjerice zaštite slobode i prava drugih ljudi. Međutim, ako će se ograničiti, njegova ograničenja moraju proći test razmjernosti (članak 16. stavak 2. Ustava). ${ }^{13}$

O tome je bila riječ u odluci Ustavnog suda br. U-III/2086/2016 od 13. ožujka 2018. u kojoj je odlučivao je li podnositelju ustavne tužbe (načelniku Policijske postaje) povrijeđeno pravo na pravično suđenje u upravnom sporu u kojem je osporavao rješenje Ureda vijeća za nacionalnu sigurnost o odbijanju zahtjeva za izdavanje uvjerenja (certifikata) o obavljenoj sigurnosnoj provjeri koji bi mu omogućio pristup klasificiranim podatcima. Ured je, naime, odbio zahtjev zbog toga što je ocjenom izvješća sigurnosno-obavještajne agencije, označenog stupnjem tajnosti ,povjerljivo“, utvrđeno da kod podnositelja postoji sigurnosna zapreka zbog neistinitog navođenja podataka u Upitniku za sigurnosnu provjeru. Također je utvrđeno da postoje i činjenice iz članka 22. Pravilnika o standardima sigurnosne provjere koje su isto tako sukladno članku 18. stavku 6. Zakona o tajnosti podataka ${ }^{14}$ sigurnosna zapreka za izdavanje certifikata. Pravilnik je označen oznakom neklasificiran, ali je neobjavljen i bio je nedostupan podnositelju. Protiv rješenja Ureda podnositelj je podnio tužbu Upravnom sudu u Osijeku. Svi dokumenti koji su korišteni, osim rješenja koje je dostavljeno podnositelju, bili su izdvojeni iz spisa i u njih je uvid mogao izvršiti samo sud, a ne i podnositelj niti njegov punomoćnik. Upravni sud odbio je tužbu podnositelja protiv koje je izjavio žalbu Visokom upravnom sudu. Nakon neuspješne žalbe podnositelj je

12 V. primjerice odluku Ustavnog suda br. U-III/2339/2009 od 28. studenoga 2012., točke 12. i 13.; odluku Ustavnog suda br. U-III/3516/2013 od 11. veljače 2016., točka 14.; odluku U-I/2753/2012 i dr. od 27. rujna 2016., točka 11.

13 Članak 16. Ustava glasi: ,, Slobode i prava mogu se ograničiti samo zakonom da bi se zaštitila sloboda i prava drugih ljudi te pravni poredak, javni moral i zdravlje.

Svako ograničenje slobode ili prava mora biti razmjerno naravi potrebe za ograničenjem u svakom pojedinom slučaju. "

14 Članak 18. stavak 6. Zakona o tajnosti podataka (NN, br. 79/07. i 86/12.) glasi: „, Sigurnosne zapreke u smislu ovoga Zakona su: neistinito navođenje podataka u upitniku za sigurnosnu provjeru, činjenice koje su posebnim zakonom propisane kao zapreke za prijam u državnu službu, te izrečene stegovne sankcije $i$ druge činjenice koje predstavljaju osnovu za sumnju u povjerljivosti ili pouzdanosti osobe za postupanje s klasificiranim podacima." 
podnio ustavnu tužbu protiv presude Visokog upravnog suda.

Ustavni sud ustanovio je da u obrazloženju osporavanih odluka nisu navedeni nikakvi detalji o neistinitim navodima podataka u Upitniku za sigurnosnu provjeru ni o drugim činjenicama koji ukazuju na postojanje sigurnosnih zapreka. U obrazloženju prvostupanjske presude navodi se da se radi o zaprekama određenim člankom 22. Pravilnika o standardima sigurnosne provjere od 30. prosinca 2013., bez navođenja sadržaja odredbe toga Pravilnika.

Raspravljanje pred sudom u predmetima koji se tiču izdavanja certifikata ograničeno je člankom 19. stavkom 3. Zakona o tajnosti podataka koji nalaže sudu da pri utvrđivanju činjenica i izvođenja dokaza kojima bi mogla nastati šteta za rad sigurnosno-obavještajnih agencija i nacionalnu sigurnost poduzme mjere i radnje iz svoje nadležnosti kojima će spriječiti nastanak štete. U tom smislu Ustavni sud je utvrdio da je u konkretnom slučaju riječ o ograničenju prava na uvid u sve dokaze zbog zaštite nacionalnoga pravnog poretka (nacionalne sigurnosti) te sloboda i prava drugih ljudi. ${ }^{15}$ Međutim, sukladno članku 16. Ustava svako ograničenje mora biti razmjerno naravi potrebe za ograničenjem u svakom pojedinom slučaju. ${ }^{16}$ Riječima Ustavnog suda: „to ograničenje ne može biti tako široko da podnositelju onemogući da učinkovito i stvarno osporava zakonitost rješenja koje pobija u upravnom sporu. To ograničenje treba se svesti na najmanju moguću mjeru koja će istovremeno zaštititi javni interes, ali i pružiti mogućnost podnositelju da uvjeri sud u opravdanost svog zahtjeva." ${ }^{17}$

U konkretnom slučaju Ustavni sud je ustvrdio da: „osporavane presude ne sadrže relevantne razloge za takva ograničenja koja bi pokazala da bi otkrivanjem sadržaja pojedinih dokumenata odnosno njihovih dijelova došlo do takvog ugrožavanja rada državnih tijela radi kojeg su ograničenja predviđena. Članak 19. stavak 3. Zakona o tajnosti podataka, prema shvaćanju Ustavnog suda, ne postavlja pred upravni sud zahtjev da potpuno onemogući stranci uvid u dostavljene dokaze, već zahtjeva da u pogledu onih dokaza otkrivanjem kojih bi mogla nastati šteta poduzme mjere i radnje kojima će spriječiti nastanak štete, pri čemu je na upravnom sudu da odluči koju će mjeru i radnju poduzeti u odnosu na koji dokaz te da tu svoju odluku obrazloži. ${ }^{\text {"18 }} \mathrm{Na}$ kraju svoje odluke Ustavni sud je zaključio da nadležni sudovi nisu proveli postupak u kojem je podnositelj na djelotvoran način mogao zaštititi svoja prava u vezi $\mathrm{s}$ provedenom sigurnosnom provjerom, odnosno da su sudovi propustili svoja pravna stajališta obrazložiti na način koji ne dovodi u sumnju u arbitrarnost postupanja i odlučivanja. ${ }^{19}$ Stoga, je Ustavni sud utvrdio da je došlo do povrede ustavnog prava na pravično suđenje iz članka 29. stavka 1. Ustava.

Važnost ove odluke Ustavnog sud ogleda se u tomu što se, čak i ako je riječ o ograničavanju uvida stranke u spis zbog zaštite nacionalne sigurnosti, pri odlučivanju o tom ograničavanju mora primijeniti načelo razmjernosti, a odluka o ograničavanju uvida mora biti dostatno obrazložena. To znači da se u njoj moraju konkretnije

15 V. točke 16 - 17. odluke br. U-III/2086/2016.

16 Ibid., točka 16.

17 Ibid., točka 17.

18 Loc. cit.

19 Ibid., točka 18. 
obrazložiti ona ograničenja koja su stvarno potrebna radi zaštite onih interesa radi kojih su ustanovljena. Ograničenja se neće smatrati suglasnima članku 29. stavku 1. Ustava ako ne postoji razuman odnos razmjernosti između sredstava koja su upotrijebljena i cilja koji se namjeravao postići.

U obrazloženju svoje odluke Ustavni sud citirao je i dijelove presude Europskog suda za ljudska prava u predmetu T.G. protiv Hrvatske ${ }^{20}$ koja će se razmotriti u idućem poglavlju.

\section{PRAVO NA UVID U SPIS KAO LJUDSKO PRAVO ZAS̆TIĆENO EUROPSKOM KONVENCIJOM}

U srpnju 2017. Europski sud za ljudska prava (dalje: Europski sud ili Sud) donio je presudu u predmetu T.G. protiv Hrvatske, kojom je utvrdio da upravni postupak, u kojem je podnositelju zahtjeva odbijeno produženje valjanosti njegova oružnog lista, nije bio proveden pošteno (povreda članka 6. stavka 1. Europske konvencije). ${ }^{21}$ Podnositelj zahtjeva prigovorio je nepravičnosti upravnog postupka jer se odbijanje temeljilo na službenim zabilješkama policije koje nisu u potpunosti bile dostupne ni njemu ni njegovom odvjetniku. Naime, člankom 9. Zakona o tajnosti podataka propisano je da se stupnjem tajnosti „ograničeno“ klasificiraju podatci čije bi neovlašteno otkrivanje naštetilo djelovanju i izvršavanju zadaća državnih tijela u obavljanju njihovih poslova. Nadalje, člankom 4. Pravilnika o načinu postupanja policijskih službenika u postupku za izdavanje odobrenja za nabavu oružja fizičkoj osobi $\mathrm{i}^{22}$ propisano je da o podatcima i obavijestima prikupljenim terenskom provjerom, policijski službenik sastavlja službenu zabilješku iz koje su razvidne okolnosti o postojanju ili nepostojanju zakonom propisanih uvjeta za izdavanje odobrenja za nabavu oružja. Službena zabilješka ne smije sadržavati podatke o izvorima prikupljenih podataka i obavijesti. Osim te službene zabilješke, policijski službenik sastavlja i izvješće o obavljenoj terenskoj provjeri u koje, uz podatke sadržane u službenoj zabilješci, upisuje i podatke o građanima od kojih je tražio i prikupio podatke i obavijesti. Izvješće se sastavlja u jednom primjerku, označava se stupnjem tajnosti „ograničeno“ i ulaže se u spis terenske provjere. Osobne podatke građana od kojih je tražio ili prikupio podatke i obavijesti sadržane u službenoj zabilješci, kao i sadržaj podataka i obavijesti koje je od njih prikupio, policijski službenik dužan je čuvati kao službene podatke i ne smije ih priopćiti podnositelju zahtjeva za izdavanje odobrenja za nabavu oružja ili drugim neovlaštenim osobama.

U konkretnom upravnom postupku, na temelju podataka i obavijesti prikupljenih od ispitanih građana, policijski službenik došao je do saznanja da je podnositelj zahtjeva sklon češćem i prekomjernom uživanju alkohola, što ukazuje na mogućnost zloupotrebe oružja. Zbog toga mu je rješenjem Ministarstva unutarnjih poslova odbijeno produženje valjanosti oružnog lista protiv kojeg je podnio tužbu Upravnom

20 Zahtjev br. 39701/14, presuda od 11. srpnja 2017.

21 Članak 6. stavak 1. u mjerodavnom dijelu glasi: „Radi utvrđivanja svojih prava $i$ obveza građanske naravi ... svatko ima pravo da ... sud pravično ... ispita njegov slučaj”."

$22 \mathrm{NN}$, br. 33/08. 
sudu. Upravni sud odbio je tužbu podnositelja obrazloživši u svojoj presudi da je pregledom povjerljivih službenih zabilješki ustanovio da je policija imala osnovane razloge za odbijanje produženja valjanosti oružnog lista. Protiv presude Upravnog suda podnositelj je podnio ustavnu tužbu koja je također odbijena s obrazloženjem da uskraćivanje pojedinosti na kojima su se temeljila izvješća o sigurnosnoj provjeri, uključujući osobne podatke o pojedincima koji su dali informacije, nije predstavljalo povredu njegovih ustavnih prava.

Sukladno ustaljenoj praksi Europskog suda, odluke koje donose upravna tijela koja sama ne zadovoljavaju zahtjeve iz članka 6 . stavka 1 . moraju biti podvrgnute naknadnoj kontroli „sudbenoga tijela koje ima punu nadležnost““. ${ }^{23}$ Nadalje, pojam poštenog suđenja podrazumijeva i pravo na kontradiktorni postupak, prema kojemu stranke moraju imati priliku ne samo obznaniti sve dokaze potrebne da bi uspjele sa svojim zahtjevima, nego i saznati za sve predložene dokaze ili dostavljena očitovanja te staviti svoje primjedbe na njih, a sve to kako bi mogli utjecati na odluku suda. ${ }^{24}$ Međutim, kao što je to Europski sud za ljudska prava objasnio u predmetima Užukauskas protiv Litve ${ }^{25}$ i Pocius protiv Litve ${ }^{26}$ u svakom sudskom postupku moguće je postojanje suprotstavljenih interesa, kao što je nacionalna sigurnost ili potreba za zaštitom svjedoka kojima prijeti opasnost od odmazde ili za čuvanjem tajnosti policijskih metoda istraživanja kaznenih djela, koji se moraju odvagati u odnosu na prava pojedinca. U nekim slučajevima može biti potrebno uskratiti određene dokaze kako bi se očuvala temeljna prava nekoga drugog pojedinca ili zaštitio važan javni interes. Međutim, člankom 6. stavkom 1. dopuštene su samo one mjere koje su strogo potrebne. Osim toga, kako bi se osiguralo da osoba ima pošteno suđenje, sve poteškoće uzrokovane ograničenjem njezinih prava moraju imati dovoljnu protutežu u postupcima koje provode sudske vlasti. ${ }^{27}$

Primjenom navedenih načela na predmet T.G. protiv Hrvatske Europski sud je potvrdio da se uvid u određene dijelove spisa predmeta može opravdati potrebom da se spriječi da neovlašteno otkrivanje uzrokuje štetu pravilnom djelovanju i izvršavanju policijskih zadaća u okviru sigurnosnih provjera u svrhu izdavanja dozvola za oružje. Međutim, u ovom predmetu Europski sud primijetio je da nije pružen niti jedan relevantan razlog koji ukazuje na to da bi otkrivanje činjenica i informacija sadržanih u povjerljivim izvješćima o sigurnosnoj provjeri podnositelja zahtjeva uzrokovalo štetu pravilnom djelovanju i izvršavanju policijskih zadaća. ${ }^{28}$ Nadalje, razlozi koje je policija navela o tomu zašto se podnositelju zahtjeva ne može izdati oružni list bili su vrlo općenite prirode (navodno jer je bio sklon uživanju alkohola). Stoga Europski sud smatra da se ne može reći da je podnositelj zahtjeva bio dovoljno upoznat s tvrdnjama protiv njega, što bi mu omogućilo učinkovito osporavanje tih tvrdnji podnošenjem dokaza koji idu u njegovu korist. Prema riječima Suda, teško je dokučiti kako se

23 Ortenberg protiv Austrije, zahtjev br. 12884/87, presuda od 25. studenoga 1994., par. 31. V. i Letinčić protiv Hrvatske, zahtjev br. 7183/11, presuda od 3. svibnja 2016., par. 46.

24 Letinčić protiv Hrvatske, op. cit., par. 49.

25 Zahtjev br. 16965/04, presuda od 6. srpnja 2010., par. 46.- 47.

26 Zahtjev br. 35601/04, presuda od 6. srpnja 2010., par. 52 - 53.

27 T.G. protiv Hrvatske, op. cit., par. 52.

28 Ibid., par. 61. 
podnositelj zahtjeva, uz tako ograničene informacije, mogao u ovom predmetu pripremiti za učinkovito osporavanje zakonitosti rješenja Ministarstva pobijanjem tvrdnji sadržanih u izvješćima. ${ }^{29}$ Mišljenje je Suda da je tako ograničeni opseg informacija dostupnih podnositelju zahtijevao od Upravnog suda da posveti posebnu pažnju i pozornost tomu da osigura da postupak donošenja odluke u najvećoj mogućoj mjeri ispunjava zahtjeve kontradiktornog postupka i jednakosti oružja. Međutim, u ovom je predmetu Upravni sud bez prisutnosti stranaka izvršio procjenu dokaza na kojima je policija temeljila svoja izvješća o sigurnosnoj provjeri podnositelja zahtjeva te je prihvatio njezina izvješća kao dovoljnu činjeničnu osnovu za odluku koja se pred njim osporavala, a da pritom nije uzeo u obzir prethodno navedena ograničenja prava podnositelja zahtjeva. Sud ne smatra da je takva procjena dokaza bila dovoljna za zaštitu interesa podnositelja zahtjeva bez da mu se dala učinkovita mogućnost da ospori činjenice na kojima se temeljilo rješenje Ministarstva. ${ }^{30}$ Stoga je presudio da je došlo do povrede članka 6 . stavka 1 . Europske konvencije.

Iz prikazane presude T.G. protiv Hrvatske važno je zamijetiti da je, sukladno članku 6. stavku 1. Europske konvencije, pri odlučivanju o uskrati uvida stranke u određene dijelove spisa, pa čak i kada je riječ o povjerljivim podatcima, potrebno razmotriti i obrazložiti na koji način bi otkrivanje podataka stranci uzrokovalo štetu suprotstavljenom legitimnom interesu koji se želi zaštititi. To je važan aspekt primjene načela razmjernosti koji će se analizirati u poglavlju 4.2. ovoga rada.

\section{OGRANIČAVANJE PRAVA NA UVID U SPIS NA TEMELJU ZAKONA O OPCEEM UPRAVNOM POSTUPKU}

Odredbom članka 84. stavka 1. ZUP-a propisano je da stranke i druge osobe koje dokažu pravni interes imaju pravo obavijestiti se o tijeku postupka i razgledati spis predmeta te o svom trošku umnožiti akte iz spisa. Međutim, u istoj odredbi izuzeti su od prava na razgledavanje i umnažanje sljedeći akti:

- zapisnici o vijećanju i glasovanju članova kolegijalnih tijela,

- nacrti rješenja,

- akti koji su propisima označeni određenim stupnjem tajnosti,

- akti čije bi priopćavanje bilo protivno interesu stranke te

- akti čije bi priopćavanje bilo protivno interesu trećih osoba.

Odredba članka 84. stavka 1. ZUP-a razlikuje se od analognih odredaba članka 80. stavaka 1., 2. i 4. prijašnjega Zakona o općem upravnom postupku (dalje: ZUP/1991) $)^{31}$ u nekoliko točaka. Za našu analizu istaknuli bismo dvije razlike. ${ }^{32}$ Prvo, sužen je krug osoba koje imaju pravo razgledavati spis i umnožiti akte iz spisa. Tablica 1. sadrži usporedni prikaz ovlaštenika sukladno prijašnjem i sadašnjem ZUP-u (u

29 Ibid., par. 63.

30 Ibid., par. 64.- 65.

31 NN, br. 53/91. i 103/96.

32 Postoje i druge razlike koje se neće detaljnije obrazlagati u ovom radu. Riječ je o tomu da se o odbijanju zahtjeva za razgledanje i prepisivanje spisa prema ZUP-u/1991 donosio zaključak protiv kojeg je bila dopuštena posebna žalba, a žalba se mogla izjaviti i kada zaključak nije bio izdan pismeno. Žalba se mogla izjaviti odmah (članak 80. stavak 6. ZUP-a/1991). 
tablici označen kao ZUP/2009).

Tablica 1. Ovlaštenici prava razgledanja spisa i umnažanja akata iz spisa

\begin{tabular}{|c|c|}
\hline ZUP/1991 & ZUP/2009 \\
\hline $\begin{array}{l}\text { stranke } \\
\text { svaka druga osoba koja učini vjerojatnim svoj } \\
\text { pravni interes } \\
\text { društvene organizacije i stručna udruženja } \\
\text { ako za to postoji opravdan interes }\end{array}$ & $\begin{array}{l}\text { stranke } \\
\text { svaka druga osoba koja dokaže svoj pravni } \\
\text { interes }\end{array}$ \\
\hline
\end{tabular}

Bitno je istaknuti da je Promjenom Ustava 2010. godine ${ }^{33}$ pravo na pristup informacijama koje posjeduju tijela javne vlasti postalo Ustavom zaštićeno pravo (članak 38. stavak 4.). No, smatramo da drukčije uređenje ovlaštenika uvida u spis u novom ZUP-u nije dovelo do smanjenja prava pravnih i fizičkih osoba koje su zainteresirane za pristup aktima koji se nalaze u spisu. Naime, osobe koje nemaju pravo pristupa aktima iz spisa na temelju ZUP-a, pristup mogu zatražiti na temelju Zakona o pravu na pristup informacijama (dalje: ZPPI). ${ }^{34}$ Međutim, korisnik prava na pristup informacijama nema pravo u uvida u cjelokupni spis, već pravo pristupa pojedinim njegovim dijelovima (npr. određenim zapisnicima, rješenjima i sl.) uz uvjete propisane ZPPI-om. Naime, sukladno članku 18. stavku 5. ZPPI-a traženje uvida u cjelokupni spis predmeta ne smatra se zahtjevom za pristup informacijama.

Druga razlika odredaba prijašnjeg i sadašnjeg ZUP-a koju bismo istaknuli, prikazana u tablici 2., odnosi se na akte koji se ne mogu razgledati niti umnažati.

Tablica 2. Akti koji su izuzeti od prava na razgledavanje i umnažanje

\begin{tabular}{|l|l|}
\hline ZUP/1991 & ZUP/2009 \\
\hline zapisnik o vijećanju i glasanju & zapisnici o vijećanju i glasovanju članova \\
službeni referati i nacrti rješenja & kolegijalnih tijela \\
drugi spisi koji se vode kao povjerljivi, ako bi & nacrti rješenja \\
se time mogla osujetiti svrha postupka, ili ako & akti koji su propisima označeni određenim \\
se to protivi javnom interesu, ili opravdanom & stupnjem tajnosti \\
interesu jedne stranke, ili trećih osoba & akti čije bi priopćavanje bilo protivno interesu \\
& stranke \\
& akti čije bi priopćavanje bilo protivno interesu \\
& trećih osoba \\
\hline
\end{tabular}

Pojedini autori u svojim komentarima prijašnjih Zakona o općem upravnom postupku ne osvrću se na razloge zašto je za pojedine akte koji se nalaze u spisu propisano da se ne smiju razgledavati i umnažati, već samo prepisuju o kojim aktima je riječ. ${ }^{35}$

35 V. Krbek, I., Zakon o opštem upravnom postupku, Zagreb, Tisak Jugoslovenske štampe, 1931., str. 55; Majstorović, B., Komentar Zakona o opštem upravnom postupku, Beograd, 
Željeli bismo se, stoga, osvrnuti na izuzimanje zapisnika o vijećanju i glasovanju članova kolegijalnog tijela (u nastavku: zapisnik o vijećanju i glasovanju) i nacrta rješenja od prava razgledavanja i umnažanja spisa. Navedeno ograničavanje, naime, propisano je još Zakonom o općem upravnom postupku iz $1930 .^{36}$ te je zadržano u svim kasnijim zakonskim tekstovima kojima se u hrvatskom pravu uređivao opći upravni postupak. ${ }^{37}$

Smatramo kako ograničavanje prava razgledavanja i umnažanja navedenih akata treba promatrati u svjetlu ranije spomenutih ustavnih odredbi, a posebno uzimajući u obzir načelo razmjernosti u zaštiti prava stranaka i javnog interesa. ${ }^{38}$ Pritom smatramo da je posebno važno i pitanje traži li stranka uvid u navedene akte tijekom vođenja postupka, tj. prije donošenja rješenja ili to čini nakon što je rješenje doneseno.

Držimo, naime, da je osnovna svrha izuzimanje zapisnika o vijećanju i glasovanju i nacrta rješenja od prava razgledavanja i umnažanja spisa u sprječavanju mogućnosti „prijevremenog“ saznanja stranaka o načinu na koji će javnopravno tijelo riješiti upravnu stvar. Naime, uvid u rezultate glasovanja članova kolegijalnog tijela ili nacrt rješenja sasvim sigurno će strankama dati jasnu sliku o tomu kako će se riješiti upravna stvar. To u višestranačkim upravnim stvarima može privilegirati stranke koje su tražile uvid u spis, a može dovesti i do nepotrebnih pritisaka na javnopravna tijela kako bi se eventualno donijelo drukčija rješenja. Stoga mislimo kako javnopravna tijela moraju izuzeti zapisnike o vijećanju i glasovanju i nacrte rješenja od razgledavanja i umnažanja kada se to zatraži prije donošenja rješenja.

Međutim, mislimo da bi u situacijama kad se razgledavanje i umnažanje zapisnika o vijećanju i glasovanju i nacrta rješenja zatraži nakon što je doneseno rješenje, javnopravna tijela trebala $u$ pravilu dopustiti takva razgledavanja $i$ umnažanja. ${ }^{39}$ Naravno, i ovdje bi trebalo provoditi test razmjernosti i uzimati u obzir

Nova administracija, 1957., str. 91; Krbek, I. Pravo jugoslavenske javne uprave, III Knjiga Funkcioniranje i upravni spor, Zagreb, Birotehnički izdavački zavod, 1962., str. 72, Jevtić, Lj., Šramek, R., Upravni postupak - opšti i posebni - i upravni spor, 6. prer. i dop. izd., Beograd, Savremena administracija, 1970., str. 90; Tomić, Z., Bačić, V., Komentar Zakona o opštem upravnom postupku, Beograd, Službeni list SFRJ, 1986., str. 122; Crnković, V., Dupelj, Ž., Primjena Zakon o općem upravnom postupku, 3. izm. i dop. izd., Zagreb, Informator, 1996., str. 50.

36 Službene Novine od 25. XI. 1930., br. 271, pod tek. br. 571, s ispravkom u Službenim Novinama od 20. XII. br. 292, pod tek. br. 624. Navedeni zakon, međutim, od razgledavanja i prepisivanja isključivao je samo zapisnik o vijećanju, dok su se nacrti rješenja (kao i ,,razni drugi spisi povjerljive prirode") isključivali samo u slučajevima kad se njihovo razgledavanje i prepisivanje protivilo javnom interesu odnosno opravdanom interesu jedne stranke ili trećih osoba, kao i ako bi se time mogla osujetiti svrha postupka. V. čl. 42. st. 3. Zakona o općem upravnom postupku iz 1930.

37 Mogućnost razgledanja zapisnika o vijećanju i glasanju izuzima i Zakon o parničnom postupku (NN, br. 53/91; 91/92; 58/93; 112/99; 88/01; 117/03; 88/05; 02/07; 84/08; 96/08; 123/08; 57/11; $148 / 11 ; 25 / 13$ i 89/14).

38 V. čl. 6. ZUP-a.

39 Smatramo da omogućavanje uvida u zapisnik o vijećanju i glasovanju svakako pridonosi mogućnosti korištenja izvanrednog pravnog lijeka - obnove postupka, jer je obnovu moguće zatražiti i ako kolegijalno tijelo koje je donijelo rješenje nije rješavalo u propisanom sastavu ili ako za rješenje nije glasovala propisana većina. V. čl. 123. st. 1. t. 4. ZUP-a. Isticanje činjenice 
moguće osujećivanje svrhe postupka i protivljenje razgledavanja i umnažanja javnom interesu, interesu stranke ili interesu trećih osoba. ${ }^{40}$

Posebno, u pogledu razgledavanja zapisnika o vijećanju i glasovanju želimo naglasiti da onemogućavanje razgledavanja i umnažanja takvih akata ne treba pravdati pozivanjem na zaštitu anonimnosti članova kolegijalnog tijela. ZUP bez ikakve dvojbe podupire ideju da upravne akte donose ljudi, službene osobe u javnopravnom tijelu, a ne apstraktna javna uprava, između ostalog to svakako čini i normiranjem da rješenja potpisuju službene osobe. ${ }^{41}$ Prema tome, držimo da nema opravdanja stajalište da članove kolegijalnih tijela treba skrivati od ,oka javnosti““42

\subsection{Način sastavljanja rješenja ako se zahtjev za razgledavanje ili umnažanje spisa odbija}

Kada stranka podnese zahtjev za razgledavanje ili umnažanje spisa, javnopravno tijelo može na nekoliko načina riješiti njezin zahtjev. Zahtjev se može:

- u cijelosti usvojiti, u tom slučaju se ne donosi rješenje već se stranci omogućava ostvarenje njezinog prava,

- u cijelosti odbiti, u tom slučaju se donosi rješenje čija izreka glasi da se odbija zahtjev stranke,

- djelomično odbiti, u tom slučaju se donosi rješenje o djelomičnom usvajanju zahtjeva, a izreka tog rješenja mora biti jasna u svom iskazu sukladno članku 98. stavku 3. ZUP-a. ${ }^{43}$

Jedna od osnovnih značajki upravnog akta je njegova obveznost. ${ }^{44}$ Ta obveznost znači da izreka rješenja obvezuje stranku, ali i javnopravno tijelo koje ga je donijelo, na način da su dužni poštovati izreku akta kojom se odlučuje o pravima, obvezama ili pravnim interesima stranke. Iz tog razloga, izreka je najvažniji dio rješenja. Sukladno ZUP-u sadržaj izreke mora biti kratak i određen. Ovisno o karakteru stvari koja se

da se uskraćivanjem mogućnosti razgledavanja i umnažanja spisa stranci ujedno onemogućava korištenje pravnih sredstava v. i u: Đerđa, D., Opći upravni postupak u Republici Hrvatskoj, Zagreb, Inženjerski biro, 2010., str. 198.

40 Upućivanje na ondašnju sudsku praksu koja je upućivala na mogućnost razgledavanja cjelokupnog spisa predmeta i nacrta rješenja tek od trenutka kad se donese i dostavi rješenje u predmetu v. u Popović, S., Komentar Zakona o opštem upravnom postupku, Beograd, Savremena administracija, 1987., str. 230.

41 V. čl. 98. st. 1. ZUP-a.

42 Željeli bismo na ovom mjestu podsjetiti na razmišljanja stara već više od trideset i pet godina: „Lista tih općih zahtjeva u pogledu sastavnih dijelova rješenja je podugačka, ali ima osnovu u politici zakonodavca da uprava treba prema svakome, a u prvom redu prema građanima, nastupati otvoreno, jer više nema posla s feudalnim podanikom, nego s modernim čovjekom koji zna svoje mjesto u društvenom sistemu. Ta će otvorenost biti afirmirana jednako kad stranka zna da je o njezinoj stvari odlučivao čovjek odnosno grupa poznatih ljudi, a ne anonimna upravna vlast, kao i naročito kad su mu saopćeni razlozi zbog kojih je došlo do odluke određenog sadržaja. "Ivančević, V., Institucije upravnog prava, Zagreb, Pravni fakultet u Zagrebu, 1983., str. 319. O navedenoj problematici v. i poglavlje 4.2. u nastavku rada.

43 Relevantni dio članka 98. stavka 3. ZUP-a glasi: „Izreka sadržava odluku o upravnoj stvari. Izreka mora biti kratka i određena".

44 V. Borković, I., Upravno pravo, Zagreb, Narodne novine, 2002., str. 382-383. 
rješava, izreka se može podijeliti i na više točaka čime se također omogućuje njezina kratkoća i jasnoća.

Budući da izreka rješenja u određenom trenutku stječe svojstvo izvršnosti, tj. mogućnost svog ostvarenja odnosno provedbe, izreka mora biti određena, a to znači da mora biti jasna u svom iskazu i točno utvrđena. Ivančević navodi još dva razloga zbog kojih je jasnoća izreke osobito važna: zato što stranka nije pozvana da sama tumači sadržaj izreke bez opasnosti da za nju nastupe neugodne posljedice, a nije ni poželjno da takvo tumačenje daje naknadno donositelj rješenja jer stranka do tog vremena ostaje u neizvjesnosti. ${ }^{45}$

Iz ustavnog značaja prava stranke da razgleda spis, i primjene načela razmjernosti, proizlazi da ako javnopravno tijelo djelomično odbija zahtjev stranke na uvid u spis, samo oni podatci odnosno dijelovi akata koji podliježu opravdanom ograničenju će se izuzeti od pristupa, a preostali dijelovi akta učinit će se dostupnim.

Budući da izreka rješenja mora biti određena, dužnost je javnopravnog tijela da u izreci rješenja precizira svaki akt koji podliježe ograničenju te da, ako je to $s$ obzirom na cjelokupan sadržaj akta moguće, navede koji će se njegovi dijelovi prekriti (zacrniti ili na drugi način učiniti nedostupnim) u odnosu na preostale dijelove akta koji će se učiniti dostupnim. Primjerice, ako neki akt sadrži osobne podatke trećih osoba, samo će se ti podatci prekriti i izuzeti od uvida te će se stranci omogućiti uvid u preostali dio akta. Ta dužnost javnopravnog tijela postoji u svakom slučaju u kojem tijelo donosi rješenje kojim djelomično odbija zahtjev stranke za razgledavanje i umnažanje spisa predmeta ili njegovih pojedinih dijelova, a ne samo u slučajevima u kojima stranka izričito zatraži od javnopravnog tijela izdvajanje, tj. prekrivanje podataka te omogućavanje uvida u preostale dijelove akta za koje ne postoje nikakva ograničenja.

Zaključno, izreka rješenja kojim je djelomično odbijen zahtjev za razgledavanje i umnažanje dokumenata koji se nalaze u spisu predmeta mora biti sastavljena tako da se:

1. jasno određuje svaki pojedini akt u odnosu na kojeg se odbija zahtjev; akt se u izreci rješenja treba precizirati prema svom nazivu, donositelju (ili tvorcu) i datumu te prema klasifikacijskoj oznaci i urudžbenom broju, ako postoje;

2. zahtjev odbija samo u odnosu na one dijelove akta koji podliježu opravdanom ograničenju od uvida na način da se oni prekriju, a da se preostali dijelovi akta učine dostupnim; izreka mora sadržavati konkretan opis podataka koji se izuzimaju od uvida. ${ }^{46}$

45 Ivančević, Institucije ... op. cit., str. 320.

46 Primjer izreke: Djelomično se usvaja zahtjev za razgledavanje i umnažanje sljedećih akata:

- Dopis (naziv javnopravnog tijela), KLASA: , URBROJ: od (datum) na način da se na istom prekrije podatak o jedinstvenom matičnom broju i vlastoručni potpis ........ te se $u$ tim dijelovima zahtjev odbija.

- Račun br. __ od (datum) na način da se na istom prekrije adresa ........ te se u tom dijelu zahtjev odbija.

- Bilješka sa sastanka (naziv tijela), KLASA: , URBROJ: od (datum) na način da se na stranici 2. istog prekriju podaci o adresi te se u tom dijelu zahtjev odbija. 
Uz izreku, i obrazloženje rješenja čini obvezatni sastavni dio svakog rješenja. ${ }^{47}$ Iznimno, u stvarima manjeg značenja u kojima se udovoljava zahtjevu stranke, a ne dira se u javni interes niti interes trećih osoba, rješenje se može sastojati samo od izreke u obliku zabilješke u spisu, ako su razlozi za takvu odluku očiti (članak 99. ZUP-a).

O načinu sastavljanja obrazloženja, Ustavni sud je u svojoj je odluci, br. U-I406/1994 i dr. iz 1999. godine izrazio pravno stajalište: „, da se pravo na žalbu, odnosno drugu pravnu zaštitu, može učinkovito ostvarivati samo ako tijelo koje je donijelo rješenje navede razloge za to rješenje, koji se onda mogu pobijati u obrani žaliteljevih prava i na zakonu zasnovanih interesa. Bez upućenosti u te razloge onemogućeno je ili bitno otežano učinkovito korištenje ustavnim pravom na žalbu odnosno drugu pravnu zaštitu. Jedino građanin kojemu su razlozi rješenja poznati može ga uspješno pobijati, ali isto tako i doći do uvjerenja o bezizglednosti žalbe protiv rješenja u kojemu razlozi nisu navedeni. Nesumnjivo je da obrazloženje određenog rješenja učvršćuje načelo zakonitosti te djeluje protiv eventualne samovolje i proizvoljnosti. Upravo se iz obrazloženja može najlakše utvrditi da li je upravno tijelo poštovalo načelo zakonitosti i postupalo na način da je u vođenju postupka i odlučivanju omogućilo strankama da što lakše zaštite svoja prava, vodeći pritom računa da ostvarenje njihovih prava ne bude u suprotnosti sa zakonom utvrđenim javnim interesom." ${ }^{\text {"48 }}$ Istom odlukom, izrazio je pravno stajalište da tek općenita zakonska naznaka o razlozima zaštite određenih interesa, a uz izostanak obrazloženja u rješenju, dovode do bitnog ograničenja temeljnih elemenata prava na žalbu, odnosno drugu pravnu zaštitu. Važnost obrazloženja istaknuta je i u prikazanoj odluci Ustavnog suda br. U-III/2086/2016 u poglavlju 2. ovoga rada.

Rješenje kojim se zahtjev za razgledavanje i umnažanje spisa predmeta djelomično ili u cijelosti odbija ograničavanje je jednog od temeljnih procesnih prava stranke u upravnom postupku. Takvo ograničenje, da bi bilo dopušteno, mora biti razmjerno naravi potrebe za ograničenjem u svakom pojedinom slučaju. Pri odlučivanju o odbijanju zahtjeva za razgledavanje i umnažanje spisa predmeta (bilo djelomično bilo u cijelosti) i sastavljanja takvog obrazloženja naročito je važna pravilna primjena ustavnog načela razmjernosti, koje se primjenjuje u svim slučajevima ograničavanja prava i sloboda stranaka. Načelo razmjernosti u zaštiti prava stranaka i javnog interesa jedno je i od temeljnih načela upravnog postupka koje je propisano u članku 6. ZUP-a, a čija relevantna odredba stavka 1. glasi: „Pravo stranke može se ograničiti postupanjem javnopravnih tijela samo kad je to propisano zakonom te ako je takvo postupanje nužno za postizanje zakonom utvrđene svrhe i razmjerno cilju koji treba postići.“49

47 Ustavni sud je 1996. godine ukinuo pojedine odredbe ZUP-a/1991 koje su dopuštale da se izostavi obrazloženje rješenja u kojem se odlučuje diskrecijskom (slobodnom) ocjenom kad je to zakonom ili uredbom izričito predviđeno (odluka Ustavnog suda br. U-I-248/1994 od 13. studenoga 1996.).

48 Odluka Ustavnog suda, br. U-I-406/1994, U-I-907/1994, U-I-418/1995 od 10. veljače 1999.

49 Članak 6. stavci 2. i 3. ZUP-a glase: “(2) Kad se na temelju propisa stranci nalaže kakva obveza, prema njoj će se primjenjivati one mjere za ispunjenje obveze koje su za nju povoljnije, ako se takvim mjerama postiže svrha propisa." 


\subsection{Primjena načela razmjernosti pri odlučivanju o ograničavanju prava na uvid u spis}

Prvi korak u primjeni načela razmjernosti je identificiranje potpada li akt (ili njegov dio) pod neki od zakonom definiranih razloga. Pri provedbi testa razmjernosti prvo je potrebno utvrditi je li ograničavanje prava stranke utemeljeno na zakonu. Kao što je već spomenuto, članak 84 . stavak 1 . ZUP-a propisuje mogućnost da se pojedini akti izuzmu od prava na razgledavanje i umnažanje, a to su zapisnici o vijećanju i glasovanju članova kolegijalnih tijela, nacrti rješenja, akti koji su propisima označeni određenim stupnjem tajnosti te akti čije bi priopćavanje bilo protivno interesu stranke ili interesu trećih osoba. To su jedini akti koji su u ZUP-u propisani kao razlozi za moguće ograničenje uvida stranke u spis predmeta, ali moguće je i da posebni zakoni propisuju i neke druge razloge. Međutim, drukčije uređenje pitanja razgledavanja spisa od onog propisanog ZUP-om mora biti nužno za postupanje u tom posebnom upravnom području i ne smije biti suprotno temeljnim odredbama i svrsi upravnog postupka (članak 3. stavak 1. ZUP-a). Osim toga, mora biti takvo da građani i pravne osobe mogu na jednostavan i djelotvoran način ostvarivati svoja Ustavom zajamčena prava i zakonom zaštićene interese (članak 81 . Zakona o sustavu državne uprave ${ }^{50}$ (dalje: ZSDU)). To je stajalište Ustavnog suda utvrđeno u odluci br. U-I-1678/2013 od 19. prosinca 2013., ${ }^{51}$ kojom su ukinuti članak 102. stavak 3. i članak 165. stavak 3. Zakona o javnoj nabavi. ${ }^{52}$ Ukinutim odredbama bilo je propisano da se određeni podatci i dokumenti iz spisa ne smiju kopirati, umnažati, reproducirati, fotografirati niti snimati već samo ručno bilježiti. ${ }^{53}$

Što se tiče kategorije akata čije bi priopćavanje bilo protivno interesu trećih osoba, važno je napomenuti da se ni jedno javnopravno tijelo ni član javnopravnog tijela ne može smatrati „trećom stranom“ u smislu odredbe članka 84. stavka 1. ZUP-a. Treće osobe koje su propisane u toj odredbi ZUP-a su privatnopravni subjekti (fizičke ili pravne osobe), čiji se podatci mogu nalaziti u spisu predmeta. Javnopravna tijela osnovana na temelju zakona osnivaju se s određenim djelokrugom poslova koje su dužna obavljati. Kada je riječ o javnoj sferi, a ne o privatnoj sferi pojedinca, nije primjenjivo uskraćivati uvid u određene podatke, kao što su npr. imena i prezimena osoba koje obavljaju određene funkcije u javnopravnim tijelima. Članovi javnopravnih tijela ne obavljaju te poslove u svom privatnom svojstvu, već kao ovlašteni nositelji javnih ovlasti. Stoga se na njih ne mogu primjenjivati razlozi zaštite

(3) Pri vođenju postupka javnopravna tijela dužna su strankama omogućiti da što lakše zaštite i ostvare svoja prava, vodeći pri tome računa da ostvarivanje njihovih prava ne bude na štetu prava trećih osoba niti u protivnosti s javnim interesom. "

50 NN, br. 150/11., 12/13. - Odluka Ustavnog suda, 93/16. i 104/16.

51 V. točku 8.3.

52 NN, br. 90/11., 83/13. i 143/13.

53 Ustavni sud utvrdio je da se ciljevi ukinutih odredaba koje dopuštaju da ponuditelji samo ručno bilježe podatke iz ponuda drugih ponuditelja, odnosno iz spisa predmeta, a zabranjuje im se da ih barem kopiraju i umnažaju (na kojem je temeljnom pravilu ustrojen upravni postupak) ne mogu smatrati legitimnim, odnosno da ograničenja (mjere) nemaju razumno i objektivno opravdanje. Budući da je utvrdio nelegitimnost cilja osporenih ograničenja (mjera), dalje nije ispitivao njihovu razmjernost (v. točke 12. - 13. odluke br. U-I-1678/2013). 
osobnih podataka kao razlog za uskratu uvida u zapisnike o njihovom radu i zaključke koje su donijeli. Moguće je u nekim slučajevima odbiti uvid u zapisnik ako je riječ o vijećanju i glasovanju članova kolegijalnih tijela, ali to se odnosi na kolegijalno tijelo koje takvim vijećanjem i glasovanjem rješava upravnu stvar koja je predmet upravnog postupka, a ne na sve zapisnike o radu pojedinih javnopravnih tijela. Kada bi se od uvida uskraćivali zapisnici o radu javnopravnih tijela time bi se u potpunosti narušilo načelo javnosti rada, kojim se osigurava transparentnost i otvorenost tijela javne vlasti te stvara osnova za povjerenje građana u rad institucija.

Drugi korak u primjeni načela razmjernosti je određivanje je li ograničenje usmjereno na postizanje nekoga legitimnog cilja (zaštićenog interesa). Primjerice, u predmetu T.G. protiv Hrvatske povjerljivost se, prema Europskom sudu, mogla opravdati potrebom da se spriječi šteta koju bi neovlašteno otkrivanje uzrokovalo u ispravnom djelovanju i izvršavanju policijskih zadaća u okviru sigurnosnih provjera u svrhu izdavanja oružnog lista. ${ }^{54}$ U prikazanom predmetu U-III-2086/2016 Ustavni sud je ocijenio da je ograničenje bilo vezano za zaštitu nacionalnoga pravnog poretka te slobode i prava drugih ljudi. ${ }^{55} \mathrm{~S}$ druge strane, u spomenutom predmetu br. U-I1678/2013 Ustavni sud je utvrdio nelegitimnost cilja osporenih ograničenja budući da zabrana kopiranja i umnažanja određenih podataka iz spisa predmeta nije imala nikakvo razumno i objektivno opravdanje. ${ }^{56}$

Zadnji korak u primjeni načela razmjernosti je utvrđivanje je li ograničenje prava stranke na razgledavanje i umnažanje spisa predmeta nužno za ostvarenje cilja koji se želi postići tim ograničenjem. Samo utvrđenje da je riječ o aktu ili dijelu akta za koji je ZUP u članku 84. stavku 1. propisao da se smije uskratiti njegovo razgledavanje ili umnažanje, još uvijek ne znači da se pristup takvom aktu treba ograničiti, tj. donijeti rješenje kojim se odbija zahtjev stranke. U ovom koraku provedbe načela razmjernosti javnopravno tijelo mora obrazložiti vjerojatnost da bi za zaštićeni interes nastala šteta. To se odnosi na sve akte navedene u članku 84. stavku 1. ZUP-a. Naime, sama činjenica da pojedini akt pripada u kategoriju moguće uskrate od uvida ne znači da bi u konkretnom slučaju zaštićeni interes doista i bio povrijeđen omogućavanjem uvida u predmetni akt. Drugim riječima, nastanak štete za zaštićen interes mora konkretan. Nije dovoljno pozvati se na razloge uskrate ili koristiti uopćene fraze poput „nastala bi šteta za interese trećih osoba“, već je potrebno te razloge utemeljiti i obrazložiti kako bi se utvrdila vjerojatnost povrede zaštićenog interesa. Ta dužnost proizlazi iz obveze javnopravnog tijela da utvrdi je li ograničavanje prava stranke na uvid u spis zaista nužno za postizanje zakonom utvrđene svrhe (čl. 6. st. 1. ZUP-a), kao i iz njegove obveze da valjano sastavi obrazloženje rješenja. ${ }^{57}$

54 T. G. protiv Hrvatske, op. cit., par. 61.

55 V. točku 16. odluke br. U-III/2086/2016.

56 V. točke 12. - 13. odluke br. U-I-1678/2013.

57 U svojoj odluci br. U-III-2086/2016, prikazanoj u poglavlju 2. ovog rada, Ustavni sud ukinuo je presude Visokog upravnog suda i Upravnog suda u Osijeku jer osporavane presude nisu sadržavale relevantne razloge za ograničenja prava stranke na uvid u određene dijelove spisa koja bi pokazala da bi otkrivanjem sadržaja pojedinih dokumenata odnosno njihovih dijelova došlo do takvog ugrožavanja rada državnih tijela radi kojeg su ograničenja predviđena (točka 17. odluke). Sudovi, pa tako i javnopravna tijela, dužni su obrazložiti ograničenja koja su 
I na samom kraju primjene načela razmjernosti, ako je javnopravno tijelo utvrdilo vjerojatnost nastanka štete za zaštićeni interes, potrebno je i da ocijeni odnos između razloga koji govore u prilog ograničenju prava stranke na uvid u spis, s jedne strane, i zaštite interesa stranke da joj se omogući uvid, s druge. Javnopravno tijelo treba uzeti u obzir vjerojatnost i ozbiljnost povrede zaštićenog interesa s jedne strane te osiguranje prava stranke na pravičan postupak $\mathrm{s}$ druge. Na temelju provedene ocjene prevladava li u konkretnom slučaju interes stranke nad mogućom štetom koja bi mogla nastati za zaštićene interese, tijelo javne vlasti će donijeti odluku o tomu hoće li i u kojoj mjeri odbiti zahtjev stranke za uvid u spis. Ako prevladava interes stranke za osiguranje njezinog prava na pravični postupak, uvid će joj se omogućiti.

\subsection{Vrijeme ostvarenja prava na uvid u spis}

ZUP ne sadrži odredbe kojim bi se pobliže uredio način ostvarenja prava na uvid u spis, odnosno vrijeme u kojem se uvid može izvršiti, osim što propisuje načelo učinkovitosti i ekonomičnosti sukladno kojem se u upravnim stvarima postupa što je moguće jednostavnije, bez odgode i uz što manje troškova, ali tako da se utvrde sve činjenice i okolnosti bitne za rješavanje o upravnoj stvari (članak 10. ZUP-a). Propisano je jedino mjesto ostvarenja prava na uvid, a to su službene prostorije javnopravnog tijela kod kojeg se vodi postupak. U opravdanim slučajevima spisi se mogu razgledati u službenim prostorijama drugoga javnopravnog tijela (članak 84 . stavak 2. ZUP-a).

Stoga se odgovor na pitanje o načinu, odnosno vremenu ostvarenja prava na uvid treba pronaći u odredbama ZSDU-a, kao i Uredbe o načelima za unutarnje ustrojstvo tijela državne uprave ${ }^{58}$ (dalje: Uredba o načelima). U tom pogledu važna je već spomenuta odredba članka 81. ZSDU-a, sukladno kojoj su tijela državne uprave dužna svoj rad i poslovanje ustrojiti tako da građani i pravne osobe mogu na jednostavan $i$ djelotvoran način ostvarivati svoja Ustavom zajamčena prava i zakonom zaštićene interese te ispunjavati svoje građanske dužnosti.

Nadalje, članak 39. Uredbe o načelima propisuje da se tjedni i dnevni raspored radnog vremena, dnevni odmor te uredovno vrijeme za rad sa strankama u tijelima državne uprave pobliže uređuju pravilnikom o unutarnjem redu tijela državne uprave. Tijela državne uprave dužna su putem sredstava javnog priopćavanja, na oglasnim pločama tijela državne uprave, odnosno na drugi prikladan način obavijestiti javnost o radnom vremenu tijela državne uprave, odnosno uredovnom vremenu za rad s građanima i drugim strankama.

Uzevši u obzir citirane odredbe, ako stranka pristupi javnopravnom tijelu tijekom radnog vremena za rad sa strankama trebao bi joj se odmah omogućiti uvid u spis njezinog predmeta. Naime, ZSDU-om je propisano da su tijela državne uprave dužna svoj rad i poslovanje ustrojiti tako da građani i pravne osobe mogu na jednostavan i djelotvoran način ostvarivati svoja Ustavom zajamčena prava i zakonom zaštićene interese. Osim toga, u skladu s načelom ekonomičnosti i učinkovitosti, u upravnim

stvarno potrebna radi zaštite onih interesa radi kojih su ustanovljena. 
stvarima trebalo bi se postupati što je moguće jednostavnije, bez odgode i uz što manje troškova i za javnopravno tijelo i za stranku. Ako stranka smatra da mu se zbog neopravdanih razloga otežava ostvarenje njezinog prava na uvid u spis, ima pravo podnijeti prigovor čelniku javnopravnog tijela na rad tijela državne uprave, kao i na nepravilan odnos državnih službenika u vezi s ostvarivanjem svojih prava i interesa (članak 84. ZSDU-a).

\section{ZAKLJUČAK}

Pravo na uvid u spis procesno je pravo zajamčeno Ustavom koje je potrebno sagledavati u sklopu prava na pravični postupak. Pravo na uvid u spis također je i ljudsko pravo zajamčeno Europskom konvencijom.

Zakoni kojima je uređen opći upravni postupak u hrvatskom pravu pravo na uvid u spis, tj. pravo na obavješćivanje o tijeku postupka, razgledavanje i umnažanje spisa jamče već skoro devedeset godina.

Osiguravanjem uvida u spis u upravnim stvarima strankama u postupcima olakšava se očitovanje o činjeničnim i pravnim pitanjima te im se omogućuje potpunija pravna borba i zaštita u svim fazama upravnog postupka. Dakako, u konačnici, omogućavanjem uvida u spis postiže se i veća kvaliteta rješenja javnopravnih tijela te osiguravanje zakonitosti u funkcioniranju javne uprave.

Zbog toga je iznimno važno da su službenici u javnopravnim tijelima svjesni važnosti prava na uvid u spis te da građanima takav uvid zaista, u skladu s propisanim ograničenjima, i omogućuju.

\section{LITERATURA}

1. Borković, Ivo, Upravno pravo, Zagreb, Narodne novine, 2002.

2. Crnković, Vladimir, Dupelj, Željko, Primjena Zakon o općem upravnom postupku, 3. izm. i dop. izd., Zagreb, Informator, 1996.

3. Đerđa, Dario, Opći upravni postupak u Republici Hrvatskoj, Zagreb, Inženjerski biro, 2010 ,

4. Đerđa, Dario, Pravila upravnog postupka u europskom pravu, Zbornik Pravnog fakulteta Sveučilišta u Rijeci, vol. 33, 1/2012, str. 109-144.

5. Đerđa, Dario, Učinak europskih pravnih pravila na pravno normiranje upravnog postupka u Hrvatskoj, Zbornik radova Pravnog fakulteta u Splitu, vol. 50, 2/2013, str. 393-427.

6. Ivančević, Velimir, Institucije upravnog prava, Zagreb, Pravni fakultet u Zagrebu, 1983.

7. Jevtić, Ljubomir, Šramek, Radomir, Upravni postupak - opšti i posebni - i upravni spor, 6. prer. i dop. izd., Beograd, Savremena administracija, 1970.

8. Krbek, Ivo, Pravo jugoslavenske javne uprave, III Knjiga - Funkcioniranje i upravni spor, Zagreb, Birotehnički izdavački zavod, 1962.

9. Krbek, Ivo, Zakon o opštem upravnom postupku, Zagreb, Tisak Jugoslovenske štampe, 1931.

10. Majstorović, Bogdan, Komentar Zakona o opštem upravnom postupku, Beograd, Nova administracija, 1957.

11. Popović, Slavoljub, Komentar Zakona o opštem upravnom postupku, Beograd, Savremena administracija, 1987. 
12. Tomić, Zoran, Bačić, Vera, Komentar Zakona o opštem upravnom postupku, Beograd, Službeni list SFRJ, 1986.

\section{PRAVNI IZVORI}

1. Konvencija za zaštitu ljudskih prava i temeljnih sloboda, NN - MU, br. br. 18/97., 6/99. pročišćeni tekst, 8/99. - ispravak, 14/02. i 1/06.

2. Pravilnik o načinu postupanja policijskih službenika u postupku za izdavanje odobrenja za nabavu oružja fizičkoj osobi, NN, br. 33/08.

3. Uredba o načelima za unutarnje ustrojstvo tijela državne uprave, NN, br. 154/11., 17/12. i $118 / 16$.

4. Ustav Republike Hrvatske, NN, br. 56/90., 135/97., 113/00., 28/01., 76/10. i 5/14.

5. Zakon o javnoj nabavi, NN, br. 90/11., 83/13. i 143/13.

6. Zakon o općem upravnom postupku, NN, br. 47/09.

7. Zakon o općem upravnom postupku, NN, br. 53/91. i 103/96.

8. Zakon o općem upravnom postupku, Službene Novine od 25. XI. 1930., br. 271., pod tek. br. 571, s ispravkom u Službenim Novinama od 20. XII., br. 292, pod tek. br. 624

9. Zakon o parničnom postupku, NN, 53/91, 91/92, 58/93, 112/99, 88/01, 117/03, 88/05, 02/07, 84/08, 96/08, 123/08, 57/11, 148/11, 25/13 i 89/14.

10. Zakon o pravu na pristup informacijama, NN, br. 25/13. i 85/15.

11. Zakon o sustavu državne uprave, NN, br. 150/11., 12/13. - Odluka Ustavnog suda, 93/16. i $104 / 16$.

12. Zakon o tajnosti podataka, NN, br. 79/07. i 86/12.

\section{PRAKSA EUROPSKOG SUDA ZA LJUDSKA PRAVA}

1. Letinčić protiv Hrvatske, zahtjev br. 7183/11, presuda od 3. svibnja 2016.

2. Ortenberg protiv Austrije, zahtjev br. 12884/87, presuda od 25. studenoga 1994.

3. Pocius protiv Litve, zahtjev br. 35601/04, presuda od 6. srpnja 2010.

4. T. G. protiv Hrvatske, zahtjev br. 39701/14, presuda od 11. srpnja 2017.

5. Užukauskas protiv Litve, zahtjev br. 16965/04, presuda od 6. srpnja 2010.

\section{PRAKSA USTAVNOG SUDA REPUBLIKE HRVATSKE}

1. Odluka Ustavnog suda br. U-I-248/1994 od 13. studenoga 1996.

2. Odluka Ustavnog suda br. U-I-406/1994, U-I-907/1994, U-I-418/1995 od 10. veljače 1999.

3. Odluka Ustavnog suda br. U-I-448/2009 i dr. od 19. srpnja 2012.

4. Odluka Ustavnog suda br. U-III/2339/2009 od 28. studenoga 2012.

5. Odluka Ustavnog suda br. U-III/3516/2013 od 11. veljače 2016.

6. Odluka Ustavnog suda br. U-I/2753/2012 i dr. od 27. rujna 2016.

7. Odluka Ustavnog suda br. U-III/2086/2016 od 13. ožujka 2018.

8. Odluka Ustavnog suda br. U-III-281/2018 od 22. svibnja 2018. 


\title{
Lana Ofak* \\ Marko Šikić**
}

\author{
Summary
}

\section{THE RIGHT TO ACCESS TO CASE FILE IN ADMINISTRATIVE MATTERS}

The paper analyses key issues related to the exercise of the right to access to case file in administrative matters. After the introductory chapter, the paper first points to the constitutional status of the right of access to the case file as an integral part of the right to a fair trial. The case law of the European Court of Human Rights is also presented in the paper, given the fact that this is a right protected by the Convention for the Protection of Human Rights and Fundamental Freedoms, which the public authorities in the Republic of Croatia must apply. The central part of the paper analyses the issues of the right of access to the case file, the exclusion of certain files from viewing and multiplication, the method of making a ruling and reasoning of the decision rejecting the access to case file, the application of the principle of proportionality when deciding on limiting the right to access and the time period of accessing into the file. The conclusion of the paper emphasizes that securing to access to case file in administrative matters ultimately achieves higher quality of the decisions of public authorities and ensures legality in the functioning of public administration.

Keywords: access to case file; fair procedure; General Administrative Procedure Act; Constitution of the Republic of Croatia; Convention for the Protection of Human Rights and Fundamental Freedoms.

\section{Zussamenfassung}

\section{DAS RECHT AUF AKTENEINSICHT IN VERWALTUNGSRECHTSSACHEN}

Der Beitrag analysiert wichtige Fragen bezüglich der Verwirklichung des Rechts auf Akteneinsicht in Verwaltungsrechtssachen. Nach dem einführenden Teil des Beitrags wird zuerst auf den Verfassungsrang des Rechts auf Akteneinsicht als Teiles des Rechts auf ein faires Verfahren hingewiesen. Da es sich dabei um das durch

* Lana Ofak, Ph.D., Associate Professor, Faculty of Law, University of Zagreb; lana.ofak@ pravo.hr.

** Marko Šikić, Ph.D., Associate Professor, Faculty of Law, University of Zagreb; marko.sikic@ pravo.hr. 
die Konvention zum Schutz der Menschenrechte und Grundfreiheiten gewährleistetes Recht handelt und da öffentlich-rechtliche Körperschaften in der Republik Kroatien die Konvention anwenden müssen, wird im Beitrag die Rechtsprechung des Europäischen Gerichtshofs für Menschenrechte dargestellt. Im zentralen Teil des Beitrags werden die Fragen des Berechtigten auf Akteneinsicht, der Beschränkung der Akteneinsicht oder dessen Kopierens, der Art der Erstellung des Tenors und der Entscheidungsgründe für die Verweigerung des Rechts auf Akteneinsicht, der Anwendung des Verhältnismäßigkeitsgrundsatzes beim Entscheiden über die Beschränkung des Rechts auf Akteneinsicht und des Zeitraums für die Verwirklichung des Rechts auf Akteneinsicht analysiert. Abschließend wird betont, dass die Ermöglichung der Akteneinsicht in Verwaltungsrechtssachen letztendlich zur Erhöhung der Qualität von Beschlüssen öffentlich-rechtlicher Körperschaften und zur Sicherung der Gesetzmäßigkeit in der Arbeit öffentlicher Verwaltung beiträgt.

Schlüsselwörter: Akteneinsicht; faires Verfahren; Gesetz über das allgemeine Verwaltungsverfahren; die Verfassung der Republik Kroatien; die Konvention zum Schutz der Menschenrechte und Grundfreiheiten .

Riassunto

\section{IL DIRITTO DI ACCESSO AL FASCICOLO NELLE QUESTIONI AMMINISTRATIVE}

Nel lavoro si analizzano questioni importanti legati alla realizzazione del diritto di accesso al fascicolo nelle questioni amministrative. Così nel lavoro, dopo una parte introduttiva, per prima cosa si evidenzia la dimensione costituzionale del diritto di accesso al fascicolo quale parte integrante del diritto ad un giusto procedimento. In considerazione del fatto che si tratta di un diritto garantito dalla Convenzione europea per la salvaguardia dei diritti dell'uomo e delle libertà fondamentali, la quale deve essere applicata dagli organi dell'amministrazione pubblica nella Repubblica di Croazia, nel lavoro si disamina anche la giurisprudenza della Corte dei diritti dell'uomo. Nella parte centrale del lavoro si analizzano le questioni della titolarità del diritto di accesso al fascicolo, della limitazione di accesso e di riproduzione di certuni atti, del modo di redazione del dispositivo e della motivazione del provvedimento con il quale si rifiuta l'accesso al fascicolo, dell'applicazione del principio di proporzionalità in occasione della decisione circa la limitazione del diritto di accesso e del tempo di realizzazione del diritto di accesso al fascicolo. Nelle conclusioni del lavoro si evidenzia come attraverso la garanzia del diritto di accesso al fascicolo nelle questioni amministrative si raggiunga anche una maggiore qualità delle decisioni della pubblica amministrazione e si garantisce la legalità nel funzionamento dell'amministrazione pubblica. 
Parole chiave: accesso al fascicolo; procedimento giusto; legge sul procedimento amministrativo generale; Costituzione della Repubblica di Croazia; Convenzione per la salvaguardia dei diritti dell'nomo e delle libertà fondamentali. 
